\title{
Factors Affecting on the Digital Piracy Behavior: An Empirical Study in Vietnam
}

\section{Quoc Trung Pham ${ }^{1}$, Nhut Minh Dang ${ }^{1}$ and Duc Trung Nguyen ${ }^{1}$}

\author{
${ }^{1}$ Ho Chi Minh City University of Technology (VNU-HCM), School of Industrial Management, \\ 268 Ly Thuong Kiet, District 10, Ho Chi Minh City, Vietnam, \\ pqtrung@hcmut.edu.vn,1870683@hcmut.edu.vn, and nguyenductrung@tdtu.edu.vn
}

Received 7 September 2018; received in revised form 24 June 2019; accepted 27 June 2019

\begin{abstract}
Digital products are illegally used in various areas in the world. This behavior causes bad effects on ecommerce activities. This study aimed to find out factors influencing digital piracy behavior in Vietnam, where digital piracy rate is fairly high. In previous research, the approach focused on separate aspects and the scope focused mainly on students. Therefore, an integrated approach could return a better result. Based on the theory of planned behavior and related researches, this study proposed an integrated model to explore the factors affecting digital piracy behavior in Vietnam. Some viewpoints that have been integrated into the proposed model include a psychological, moral, legal, economic and technological viewpoint. The sample consists of 264 people in Ho Chi Minh City, Vietnam. The results showed that the perceived behavioral control strongly influences the intention, and then on the digital piracy behavior. Besides, perceived behavioral control is influenced by technology development and perceived risk. This research confirmed most of the proposed hypotheses and showed the important role of technology in predicting this kind of behavior in Vietnam. Based on the findings of this study, several suggestions have been made to mitigate the digital piracy situation in Vietnam.
\end{abstract}

Keywords: Digital piracy, Intellectual property, E-commerce, Digital product, Security, Vietnam 


\section{Introduction}

According to a report by Business Software Alliance [7], about 39\% of computer software installed in the world are unlicensed or illegally used. Based on this report, the percentage of digital piracy (unlicensed computer software) in Vietnam is $78 \%$ in 2015 . Although this number gradually decreased in recent years $(81 \%$ in $2013,85 \%$ in 2009$)$, it is still high in comparison with other countries in the region and in the world (Malaysia 53\%, Thailand 69\%, China $70 \%$, Asia $61 \%$ ). Therefore, exploring the impact factors of digital piracy in Vietnam is a need for understanding the causes of this unethical behavior and for suggesting suitable solutions to develop a digital economy in Vietnam.

Digital piracy behavior is defined as the consumption of an illegal copy of digital products or services, such as e-book software, music, video... This behavior proves to be a harmful activity and a thread for various industries [13]. Some factors explained for digital piracy could be found in several theories, such as psychological factors, economic factors, ethical factors, lack of regulations, or cultural factors. Other researches mentioned about self-efficacy, expectation, and social interaction as causes for digital piracy behavior.

For digital products, the consumer can realize easily whether they are illegal or not. Therefore, purchasing or utilizing decisions mostly come from the consumer's intention. However, economic factors are not enough for explaining why digital piracy is high in rich countries (Saudi Arabia, 52\%; Iceland, 49\%) and low in poor countries (South Africa, $35 \%$; Slovakia, 43\%) [7]. So, recent researches focused on the ethical aspect of digital piracy behavior. Moreover, legal \& justice perception aspects also help to explain the intention to use illegal digital products/ services.

Many previous pieces of research based on the theory of planned behavior (TPB) for exploring the impact factors of digital piracy behavior, such as [25], [42]... Recently, researchers on this topic tried to add some other viewpoints in their research models. However, these researches focused on a separate viewpoint of the above aspects (psychology, ethics, justice, technology, economic...), and there is a lack of an integrated viewpoint on this problem. Besides, the scope of previous researches focuses mostly on students (not financial independence), or on a specific kind of digital products (software, music). Therefore, an integrated approach should be used for exploring this behavior, especially the simultaneous affection of various factors on digital piracy behavior. The research model should be tested in a broader sample including both students and workers, and the scope should be extended to cover various kinds of digital products or services.

Moreover, there is a lack of research on this topic in the Vietnam context. So, more research should be conducted to fill this research gap in Vietnam. Therefore, the overall goal of this research is to form an integrated model based on the previous researches, such as TPB, UTAUT, and related ones, to explore the factors affecting on the digital piracy behavior in Vietnam. The specific research objectives of this research could be summarized as follows: (1) To identify and to measure the impact of several factors on the intention and the behavior of digital piracy in Vietnam, and (2) Give some recommendations to prevent digital piracy behavior in Vietnam context.

The rest of the paper is organized as follows: section 2 presents some concepts and related research, followed by the research model and hypotheses, section 4 offers the research method, then section 5 summarizes data analysis results, section 6 presents some findings and managerial implications, and the final section is the conclusion.

\section{Concepts \& Related Researches}

According to Vietnam Ministry of Justice [37], digital products are contents or information products, including text, data, photo, music, multimedia..., which could be displayed, stored, and transferred in digital form through the internet. Some typical digital products include music, video, film, e-book, e-magazine, and software. These digital products are protected mostly by copyright regulations.

Digital piracy is a behavior of illegal copy or download of a copyrighted digital product (software, multimedia file) [3]. It is often conducted by an individual for the personal use of unlicensed software or other digital products. Some digital piracy behaviors may include self-hack, self-crack, use of cracked software, store/share of illegal digital products, share cracking experience, encourage illegal use... The intention of digital piracy is a willingness of a person to do a specific behavior, which will determine whether that person could do the behavior or not [36]. Intention to digital piracy often depends on several factors, such as attitude, knowledge, technical capability, social impact... According to Venkatesh et al. [35], the intention of digital piracy has a positive direct impact on digital piracy behavior.

Intellectual property is any form of knowledge or expression created partly or wholly with one's intellect and which can be legally protected [8]. Individuals and/or institutions can own the products of their creativity and innovation in the same way they can own physical property. An owner of intellectual property can control and receive payment for its use, so the intellectual property has value in the marketplace. There are four main types of statutory intellectual property protection: patents, trademarks, designs, and copyrights. According to the intellectual property law of Vietnam [26], there are three main groups of items protected by the intellectual property law, including authorship \& 
related rights, industrial property, and agricultural property. Digital piracy is a form of breaking intellectual property laws (copyright) and should be explored by the regulation recognition of the user.

Previous researches about digital piracy could be classified into 4 groups, which try to answer the main questions of this behavior, including (1) Why did people commit to digital piracy? (2) What are the main factors affecting digital piracy? (3) Which level should we offer a digital product for free? and (4) What should we do to control or prevent digital piracy behavior? In this study, the $2^{\text {nd }}$ question would be answered first, and the findings could be used to answer other questions.

Most of the recent researches on digital piracy based on TPB [1] and some other theories for explaining digital piracy behavior from the psychological and ethical viewpoint. Previous theories to answer to the above questions could be grouped into 3 main groups of factors for exploring digital piracy behavior as follows:

- Personal factors, such as age, gender, income, the frequency of computer use... ([30], [44]).

- Social and contextual factors, such as social interactions, industrial factors, organizational culture and regulation factors ([13], [20], [25], [38]).

- Psychological and ethical factors, such as self-control, attitude, cognition, ethical value, habit and past behavior ([11], [18], [22], [42]).

The following table (Table 1) summarized some of the previous researches related to this topic in various countries.

Table 1: Summary of previous researches on digital piracy

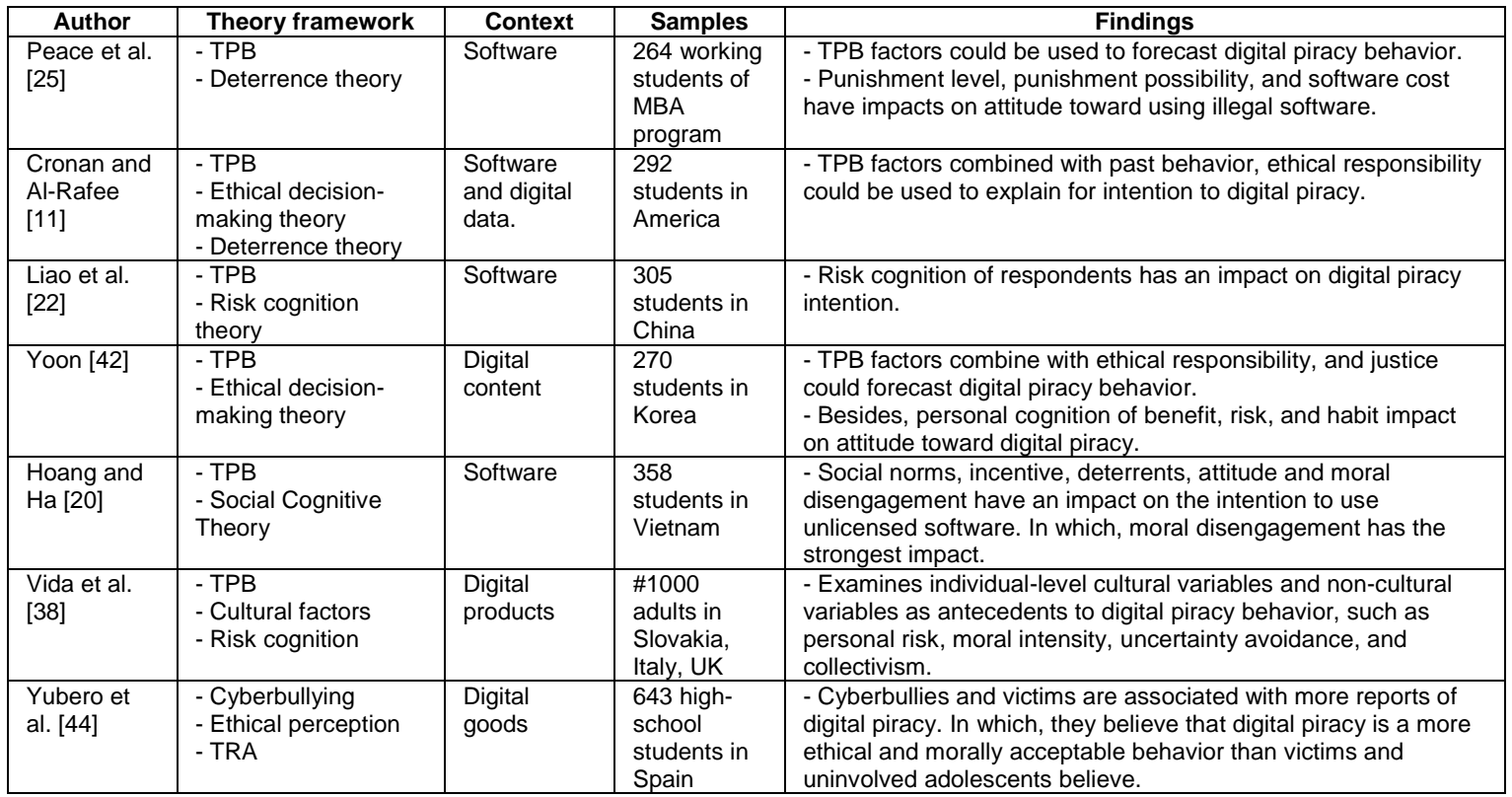

Most of the above researches used the Theory of Planned Behavior (TPB) or Unified Theory of Acceptance and Use of Technology (UTAUT) as a base. TPB model, developed by Ajzen [1], suggested three factors impacting on intention and behavior of a person, including attitude, subjective norm, and perceived behavioral control. UTAUT, built by Venkatesh et al. [35], formulated with 4 core constructs of intention and use as performance expectancy, effort expectancy, social influence and facilitating condition. In general, based on these 2 theories, the factors affecting digital piracy could be summarized into three core factors: attitude toward behavior (including performance expectancy \& effort expectancy), social influence (or subjective norm), and environment's influence on behavior (perceived behavioral control or facilitating condition). These 3 groups of influences could be used to predict people's volitional behaviors or digital piracy behaviors in this context.

However, the aim of the research is to explain rather than merely predict piracy, it is necessary to identify actionable influences on the behavior of digital piracy. The concepts of attitude, social influence, and environment's influence are too abstract to be used for meaningful intervention to reduce piracy. Therefore, there is a need to explore other factors that could be used in explaining digital piracy, such as regulation, risk, moral, technology...

In theory, regulations on intellectual property protection will help to mitigate digital piracy. But, in practice, regulation recognition and social acceptance are more important in preventing digital piracy [43]. There are many countries which lack an effective mechanism to protect intellectual properties [24], and Vietnam is one of them. According to 
Gopal et al. [14], the Internet supports digital piracy and it makes intellectual property regulations more difficult to be executed in practice. Although Gopal et al. [14] could not confirm the impact of regulation recognition on music piracy intention, it is necessary to evaluate this influence in a broader context. Therefore, regulation recognition or a personal perception about the legal results of punishment in pirating digital products should be used as an antecedent of personal intention toward digital piracy.

Moreover, different from other criminal activities, digital piracy is perceived as a relatively un-harmful activity [31] although it causes a huge economic loss for software companies. According to Peace et al. [25], perceived risk or a personal perception of the negative results of digital piracy plays an important role in preventing digital piracy. In other research, perceived risk and punishment possibility are realized to have some negative impacts on the attitude of the pirates [10]. Therefore, the perceived risk could change a personal attitude toward digital piracy and it reduces the facilitating conditions for this behavior ([25], [42]).

Besides, moral obligation is often used to explain digital piracy behavior. This factor is also used in ethical theory in IT to forecast ethical behavior [16]. Some researches confirmed that moral obligation has a positive impact on digital piracy ([11], [42]), but other research of [3] didn't confirm this impact. Moral obligation is an ethical norm which plays an important role in establishing a personal ethical belief. So, in this research context, moral obligation is considered an antecedent of the subjective norm [42]. Different from Yoon [42], in which, the moral obligation has both direct impact and indirect impact on digital piracy intention, in this study, the only indirect impact of moral obligation on the intention toward digital piracy through social norm is considered in the research model.

On the other hand, in the digital society, information technology develops very fast. Technology development helps to increase the possibility of Internet access and the availability of support technologies for digital piracy, such as filesharing, cracking, hacking... With the fast development of technology, it is now easier for users to conduct digital piracy behavior, especially in the form of file-sharing [25]. Internet access and sharing technologies could have impacts on digital piracy [6]. This factor was not mentioned in previous research of Yoon [42], but it is a determinant of the perceived behavioral control of the users. So, technology development could be added as an antecedent of perceived behavioral control of the pirates ([2], [35]).

In summary, the integrated research model should include 4 key factors identified as the distal influences on digital piracy: regulation recognition, perceived risk, moral obligation, and technology development. Besides, most of the previous researches focused on students, who have low income and not financial independence, and these researches only focused on the intention rather than on the behavior of digital piracy. These limitations could reduce the possibility to generalize the analysis results and should be overcome in this research. Therefore, an integrated approach for understanding digital piracy behavior of different users from different viewpoints could be an ideal solution. From the above analysis, this research tries to extend the scope of samples to cover both students and working people and the digital products in this research are not limited in software as in the previous researches.

\section{Research Model and Hypotheses}

Based on the above analysis, the core of research model is established from TPB \& UTAUT, which include three main factors affecting on the intention of digital piracy: attitude, subjective norm, and perceived behavioral control. The intention of digital piracy will have an impact on digital piracy behavior. Moreover, in order to increase the applicability of the model and to integrate various viewpoints in a relatively coherent model, some other factors have been added to the proposed research model, including: regulation recognition, moral obligation, perceived risk and technology development ([14], [25], [38], [42][14]). Some main factors of the research model could be defined as follows:

- Subjective norm: personal perception about whether important people to him/her agree with that action or not.

- Attitude: personal judgment or estimation about the level of benefit of a behavior.

- Perceived behavioral control: level of control or easiness of action depending on his/her capability or technology.

- Moral obligation: personal perception about whether an action is considered right or wrong (moral viewpoint).

- Perceived risk: personal perception of the negative results of digital piracy action.

- Technology development: the easiness of Internet access and the availability of support technologies for digital piracy, such as file-sharing, cracking, hacking... 
- Regulation recognition: a personal perception about the legal results of punishment in conducting digital piracy

Moreover, some demographic factors, such as age, gender, career, profession, income, etc...., are also included in the suggested research model for evaluating the impact of personal factors on digital piracy behavior. In general, the proposed research model could be summarized in the following figure (Figure 1).

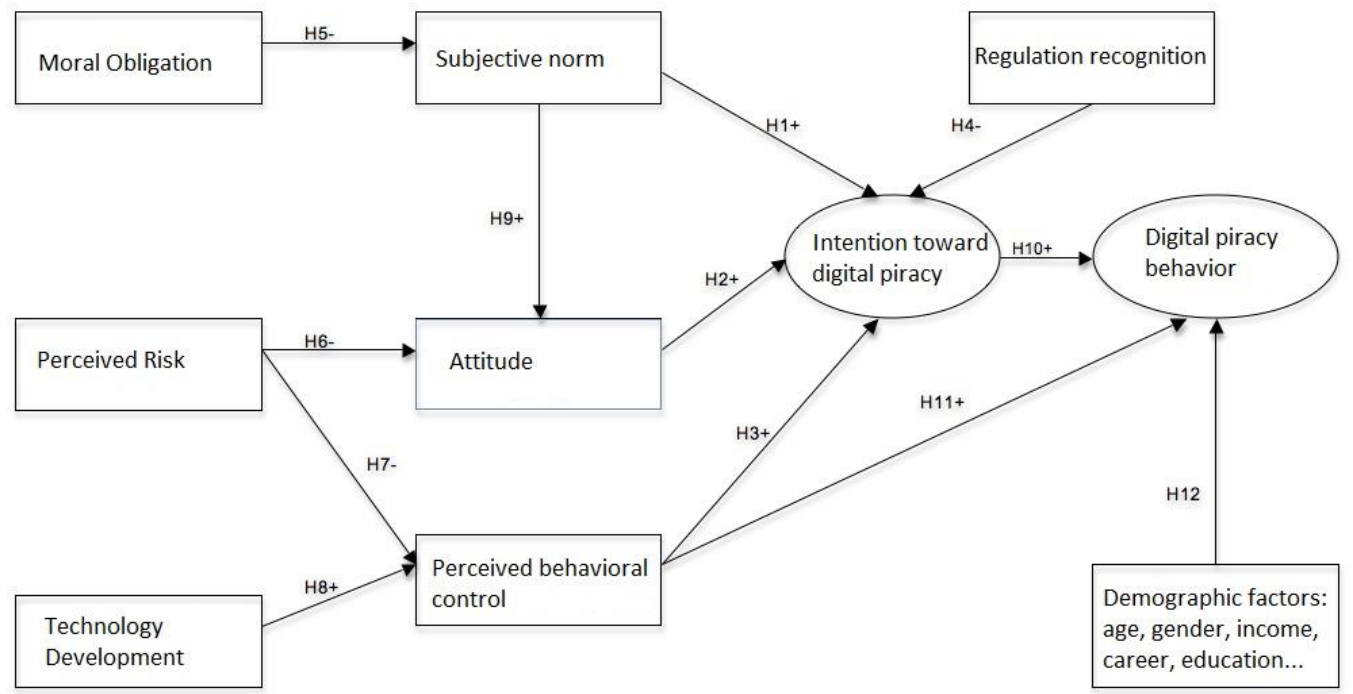

Figure 1: The proposed research model (square: impact factors, circle: dependent factors)

Based on TPB [1] \& UTAUT [35], three main factors positively affecting the behavioral intention toward digital piracy are attitude, subjective norm, and perceived behavioral control. Therefore, hypotheses $\mathrm{H} 1, \mathrm{H} 2$, and $\mathrm{H} 3$ could be stated as follows:

\section{$H 1$ (+): Subjective norm has a positive impact on the intention to digital piracy.}

H2 (+): Attitude has a positive impact on intention to the digital piracy.

H3 (+): Perceived behavioral control has a positive impact on the intention to digital piracy.

Most of the people who pirated digital products didn't realize that it is an illegal action [40]. Therefore, if the regulation on protecting the intellectual property is formed, applied, and broadcasted to everybody, it will help to prevent the intention to commit digital piracy behavior [5]. Besides, information or news about the legal punishment of digital piracy will help to reduce this behavior [4]. Therefore, hypothesis $\mathrm{H} 4$ could be stated as follows:

\section{H4 (-): Regulation recognition has a negative impact on the intention to digital piracy.}

Moral obligation is mentioned in previous researches about copyright infringement. This factor is also used in ethical decision-making theory to forecast about ethical intention and behavior. Ajzen [1] argued that moral obligation has an impact on the intention in the context of unethical behavior. According to Yoon [44], the moral obligation can play an important role in establishing personal belief and subjective norms. The moral obligation could help to prevent digital piracy through the social norm. Therefore, hypothesis $\mathrm{H} 5$ could be stated as follows:

\section{H5 (-): Moral obligation has a negative impact on the subjective norm toward digital piracy.}

The perceived risk could be considered a personal belief about the negative consequences of digital piracy behavior [10] and the risk of punishment has a greater impact on attitude toward digital piracy behavior [38]. Besides, according to Deterrence theory, possible risks and severity of punishment can impact on the attitude of digital piracy [25]. Besides, in previous researches on copyright infringement, the possibility to be caught and the punishment could prevent digital piracy behavior. The higher of the risk, the lower the perceived behavioral control [25].Therefore, hypothesis $\mathrm{H} 6$ and $\mathrm{H} 7$ could be stated as follows:

H6 (-): Perceived risk has a negative impact on the attitude toward digital piracy.

H7 (-): Perceived risk has a negative impact on the perceived behavioral control toward digital piracy. 
In the UTAUT [35], perceived behavioral control could be seen as facilitating conditions for conducting digital piracy behavior. According to Gopal et al. [14], the Internet supports digital piracy and technology development makes it easy for pirates. Moreover, the availability of Internet connection and the development of sharing technologies could facilitate digital piracy through perceived behavioral control ([6], [14], [25]). Therefore, hypotheses H8 could be stated as follows:

H8 (+): Technology development has a positive impact on the perceived behavioral control toward digital piracy.

According to Al-Rafee and Cronan [3], the subjective norm has an impact on personal attitude toward behavior. Applying TPB in ethical behavior, the addition of the impact of subjective norm on the attitude could improve significantly the fit of the model [8]. Besides, another research of Liao et al. [22] also confirmed that the subjective norm has a positive impact on the attitude toward digital piracy. Therefore, hypothesis $\mathrm{H} 9$ could be stated as follows:

\section{$H 9(+)$ : Subjective norm has a positive impact on the attitude toward digital piracy}

According to TPB [1], digital piracy behavior is influenced by the intention of digital piracy. Besides, according to UATUT [35], perceived behavioral control (or facilitating conditions) could have a positive impact on digital piracy behavior. Therefore, hypotheses $\mathrm{H} 10, \mathrm{H} 11$ could be stated as follows:

H10 (+): Intention toward digital piracy has a positive impact on digital piracy behavior.

$H 11$ (+): Perceived behavioral control has a positive impact on digital piracy behavior.

Moreover, previous researches ([12], [44]) showed that demographic factors, such as gender, age, education level, career, major, and income also have impacts on digital piracy behavior. Therefore, hypothesis $\mathrm{H} 12$ could be stated as follows:

H12a: Gender of users has an impact on their digital piracy behavior.

H12b: Age of users has an impact on their digital piracy behavior.

H12c: Education level of users has an impact on their digital piracy behavior.

H12d: Career of users has an impact on their digital piracy behavior.

H12e: Major of users has an impact on their digital piracy behavior.

H12f: Income of users has an impact on their digital piracy behavior.

\section{Research Method}

The research will pass through two stages, Pilot test $(n=20)$ for primary test and finalize the questionnaire, and then, Quantitative phase (a survey is conducted with $n=264$ ) for testing the reliability of scales and analyzing the results. The pilot test aims to modify the original scales for adapting with Vietnamese context through an interview session with 20 respondents (5 IT experts, 5 IT managers, and 10 users) before quantitative data collection process. The quantitative phase aims to test the reliability of the measurement scales and to test the proposed hypotheses.

Measurement Scales. The measurement scales used for this research based on TPB, such as attitude (4 items), subjective norm (4 items), perceived behavioral control (4 items), and intention ( 3 items) have come from Taylor and Todd [32]. The measurement scales for digital piracy behavior (4 items) derived from Venkatesh et al. [35]. Moral obligation (6 items) and regulation recognition (3 items) are based on Cronan et al. [11], Haines et al. [15], and Sang et al. [28]. Technology development (4 items) is based on Wulandari [41]. Perceived risk (5 items) is based on Peace et al. [25], and Shang et al. [29]. All measurement scales are 5 levels of Likert scales. After the primary test, the measurement scales are revised (see the appendix A) and could be used for quantitative research. The final questionnaires are then sent directly to respondents through online (shared link on the social network and e-mail list) and offline channel (papers scattered conveniently in universities and shopping centers in Ho Chi Minh City) for data collection.

Sample Size. According to Nguyen \& Nguyen [23], the size of a sample is usually determined under this equation: $\mathrm{n}$ $>=50+8 \mathrm{~m}$, in which $\mathrm{m}$ is the number of variables used in the model. In this study, there are 10 variables. So, the minimum size of the sample must greater than 130 respondents. The larger size of the collected sample, the more rational and typical the results and the lower the errors. So it would consider being an acceptable sample with $>=$ 200 respondents.

Data Analysis Methods. After collecting the data, the questionnaires are audited before being processed by the SPSS software version 22.0. Data analysis is executed by both SPSS and IBM's Analysis of Moment Structures 
(AMOS) version 20.0 on Windows operating system. The structural process of analyzing data in this research includes the below stages: Descriptive Statistics, Assessment of Measurement Scales, Exploratory Factor Analysis, Confirmatory Factor Analysis, and Structural Equation Modeling for testing model and hypothesis. Finally, analysis of variance (ANOVA) and t-test analysis are used to examine the impact of demographic factors on digital piracy behavior $(\mathrm{H} 12)$

\section{Analysis Results}

In this section, some main data analysis results will be presented, including: (1) descriptive statistics of sample, (2) preliminary assessment of measurement scales using Cronbach Alpha test, Exploratory Factor Analysis, and Confirmatory Factor Analysis, (3) the hypothesis and model test using Structural Equation Model Analysis, (4) ANOVA and t-test, and finally (5) result discussion.

\subsection{Sample Description}

The survey was conducted in Ho Chi Minh City (HCMC) from July 2017 to September 2017, including both online and offline method. Ho Chi Minh City is the big city in the south of Vietnam and it is considered a dynamic socioeconomic center in Vietnam with a population of more than 8 million people. So, the data collected in HCMC could be represented for the whole population in Vietnam. The questionnaire has 3 parts: (1) general introduction, (2) main factors of the research model, and (3) demographic factors. The convenience sampling method was used for collecting the data. In order to increase the diversity of samples, paper questionnaires were scattered at various locations in HCMC, such as universities, trading centers, parks, and cafeterias.

There are 291 collected samples, in which 264 samples are valid for data analysis ( $76 \%$ offline, $24 \%$ online). In 264 respondents, the age range from $18-25$ is $56.1 \%$, from $26-35$ is $38.3 \%$. About the education level of respondents, University/College degree is the majority $(76.5 \%)$, and then post-University degree (17.8\%). The percentage of workers is $56.8 \%$ and of students is $43.2 \%$. The major of respondents diversifies in various groups (Economics/ Management $32.2 \%$, IT/Electronics 30.3\%, and Other engineering 37.5\%). About the income of samples: less than 3 million VND. per month is $41.3 \%$ (mostly students), from 7-15 million VND. is $29.2 \%$, and more than 15 million VND. is $19.3 \%$. In general, the above rates are similar to the distribution of total digital users in Vietnam [34].

\subsection{Preliminary Assessment of Measurement Scales}

Cronbach Alpha Analysis. The reliability of all measurement scales is tested by Cronbach Alpha test. Analytical results showed that all Cronbach Alpha coefficients satisfied the requirement $(>0.7)$. The lowest coefficient is Regulatory recognition (0.755), and the highest coefficient is Intention toward digital piracy (0.865). All variables have item-total correlation $>0.5$. Therefore, all measurement scales are suitable to be used for EFA test.

Exploratory Factor Analysis (EFA). EFA is used to test the measurement scales in the many aspects, such as the uni-dimensionality, reliability and construct validity, including convergent validity and discriminant validity. The method Principal Axis Factoring is selected and the Varimax rotation method is used to support the interpretation of factors [16]. In the EFA test, KMO and Bartlett's test is used for evaluating the scales. After the EFA test, the results showed that the KMO coefficient $=0.827>0.5$ and Sig. $=0<0.05$. So, the Bartlett test is significant and could be used. The total variance extraction is $73.192(>50 \%)$, so EFA test is applicable. The result could be summarized in the following table (Table 2).

According to this result, the loading factors of Subjective norm (SBN) are from 0.717 to 0.772 , Technology development (TECH) from 0.713 to 0.829 , Intention (INT) from 0.720 to 0.865 , Moral obligation (MO) from 0.777 to 0.833 , Perceived behavioral control (PBC) from 0.759 to 0.815 , Regulation recognition (PL) from 0.738 to 0.825 , Perceived risk (PR) from 0.774 to 0.799 , Attitude (ATT) from 0.750 to 0.827 , and Digital piracy behavior (UB) from 0.679 to 0.826 , All scales are matching requirements of reliability, uni-dimentionality, convergent validity and discriminant validity. However, EFA does not provide a tool to confirm a theory. According to Nguyen \& Nguyen [23], testing a measurement model is needed with the support from CFA.

Table 2: The final exploratory factor analysis result

\begin{tabular}{|l|l|l|l|}
\hline \multicolumn{2}{|l|}{ KMO. / Significance } & $0.827 \quad / \quad 0.000$ \\
\hline Extracted variances & 73.192 \\
\hline \multirow{2}{*}{ Scales } & \multirow{2}{*}{ Code } & Variables & $\begin{array}{l}\text { Factor } \\
\text { Loadings }\end{array}$ \\
\hline \multirow{3}{*}{ Subjective norm } & sbn1 & Most of the people important to me would disapprove DP & 0.755 \\
\cline { 2 - 4 } & sbn3 & No one important to me thinks it is okay to commit DP & 0.772 \\
\cline { 2 - 4 } & sbn2 & Most people important to me look down on me if I commit DP & 0.769 \\
\cline { 2 - 4 } & sbn4 & My colleagues think digital piracy behavior is wrong & 0.717 \\
\hline Technology development & tec2 & The access and download speed is high & 0.829 \\
\cline { 2 - 4 } & tec1 & The Internet connection in various forms is available. \\
\hline
\end{tabular}




\begin{tabular}{|l|l|l|l|}
\hline Table 2: continuation & tec3 & There are many online communities sharing experience in DP & 0.718 \\
\hline & tec4 & It is easy to access P2P file-sharing sites (F-share, 4share...) & 0.713 \\
\hline \multirow{4}{*}{ Intention toward digital piracy } & int1 & I intend to pirate digital products in the near future & 0.865 \\
\cline { 2 - 4 } & int2 & If I have a chance, I will pirate digital products & 0.847 \\
\cline { 2 - 4 } & int3 & I never commit digital piracy & 0.720 \\
\hline Moral obligation & mo3 & It would be morally wrong for me to pirate digital products & 0.833 \\
\cline { 2 - 4 } & mo1 & I would feel guilty if I pirated digital products & 0.807 \\
\cline { 2 - 4 } & mo2 & To pirate digital products goes against my principles & 0.777 \\
\hline Perceived behavioral control & pbc3 & I could find pirated digital products if I wanted to & 0.815 \\
\cline { 2 - 4 } & pbc2 & I have the ability to make use of pirated digital products & 0.769 \\
\cline { 2 - 4 } & pbc1 & For me, it is easy to possess pirated digital products & 0.759 \\
\hline Regulation recognition & pl2 & Laws about downloading unlicensed software are not enforced & 0.825 \\
\cline { 2 - 4 } & pl4 & In general, digital piracy is unjust & 0.790 \\
\cline { 2 - 4 } & pl3 & Digital piracy is unfair to the producer of digital products & 0.738 \\
\hline Perceived risk & pr3 & I would receive a heavy fine for infringement of the IP law & 0.799 \\
\cline { 2 - 4 } & pr1 & If I pirated digital products, I would probably be caught & 0.796 \\
\cline { 2 - 4 } & pr2 & I would be arrested if I used pirated digital products & 0.774 \\
\hline Attitude toward digital piracy & att1 & Digital piracy is a wise idea & 0.827 \\
\cline { 2 - 4 } & att2 & Digital piracy is a beneficial idea & 0.808 \\
\cline { 2 - 4 } & att3 & Digital piracy is a good idea & 0.750 \\
\hline Digital piracy behavior & ub3 & I often share pirated digital products & 0.826 \\
\cline { 2 - 4 } & ub4 & I encouraged other people to use pirated digital products & 0.799 \\
\cline { 2 - 4 } & ub2 & I often used pirated digital products & 0.679 \\
\hline
\end{tabular}

Confirmatory Factor Analysis (CFA). CFA analysis results (Figure 2) showed that the coefficient of TLI, CFI $\geq 0.9$, $\mathrm{CMIN} / \mathrm{df} \leq 2$ and RMSEA $\leq 0.08$ ( $\mathrm{TLI}=0.906 ; \mathrm{CFI}=0.922 ; \mathrm{RMSEA}=0.055$ and $\mathrm{CMIN} / \mathrm{df}=1.792)$. Therefore, the model is fitted with sample data [23]. All standardize coefficients are satisfied (>0.5), so the measurement scales are convergent. Besides, Table 3 showed that all of the composite reliability $(\mathrm{CR})$ scores are greater than $0.60(0.791$ $0.870)$, and all of the average variance extracted (AVE) scores are greater than $0.50(0.558-0.693)$. So, they are suitable for the requirements.

Table 3: Summary of composite reliability \& average variance extracted scores

\begin{tabular}{|l|l|l|}
\hline Factor & Composite Reliability (CR) & Average Variance Extracted (AVE) \\
\hline Attitude (ATT) & 0.791 & 0.558 \\
\hline Subjective Norm (SBN) & 0.837 & 0.566 \\
\hline Perceived Behavioral Control (PBC) & 0.798 & 0.570 \\
\hline Intention (INT) & 0.870 & 0.693 \\
\hline Moral obligation (MO) & 0.844 & 0.644 \\
\hline Perceived risk (PR) & 0.819 & 0.602 \\
\hline Regulation recognition (PL) & 0.770 & 0.534 \\
\hline Technology development (TECH) & 0.819 & 0.534 \\
\hline Digital piracy behavior (UB) & 0.801 & 0.576 \\
\hline
\end{tabular}

\subsection{Structural Equation Model Analysis (SEM)}

The SEM analysis result for the 1 st time could be summarized as follows: Chi-square $=690.084 ; \mathrm{df}=360 ; \mathrm{p}-$ value $=0.00 ;$ Chi-square $/ \mathrm{df}=1.917 ; \mathrm{TLI}=0.893 ; \mathrm{CFI}=0.905 ; \mathrm{RMSEA}=0.059$. All coefficients are satisfied, except $\mathrm{TLI}(<$ 0.9). Based on Modification Indices (MI), some correlations should be added to improve the fitness of the model (TECH2 and TECH4, SBN4 and SBN2, SBN4 and SBN3, SBN1 and SBN3).

After modification, the result could be summarized as follows: Chi-square/df=1.855; TLI=0.90; CFI=0.912; and RMSEA $=0.057$. Therefore, the model is fitted with sample data [23]. Based on the SEM result, the hypothesis test could be summarized in the following table (Table 4).

\subsection{ANOVA \& t-Test (Testing Hypothesis H12)}

Between gender groups (H12a). Independent sample t-test is used for testing the difference in digital piracy behavior between the male and female group. Levene test for the assumption homogeneity of variances has a sig. $=0.956>0.05$, this result showed that variances of 2 groups are not different. In the result of Independent Samples Test, "Equal variance assumed" has a sig. $=000<0.05$. Therefore, there is a difference in digital piracy behavior between the male and female group.

Between different age, education level, career, major, and income. ANOVA test is used for testing the difference in digital piracy behavior between groups classified by age, education level, career, major, and income. The analysis results could be summarized in the following table (Table 5). 
Chi-square $=605,689 ; \mathrm{df}=338 ; \mathrm{P}=, 000 ;$
Chi-square $/ \mathrm{df}=1,792 ;$

$\mathrm{GFI}=, 867 ; \mathrm{TLI}=, 906 ; \mathrm{CFI}=, 922$;

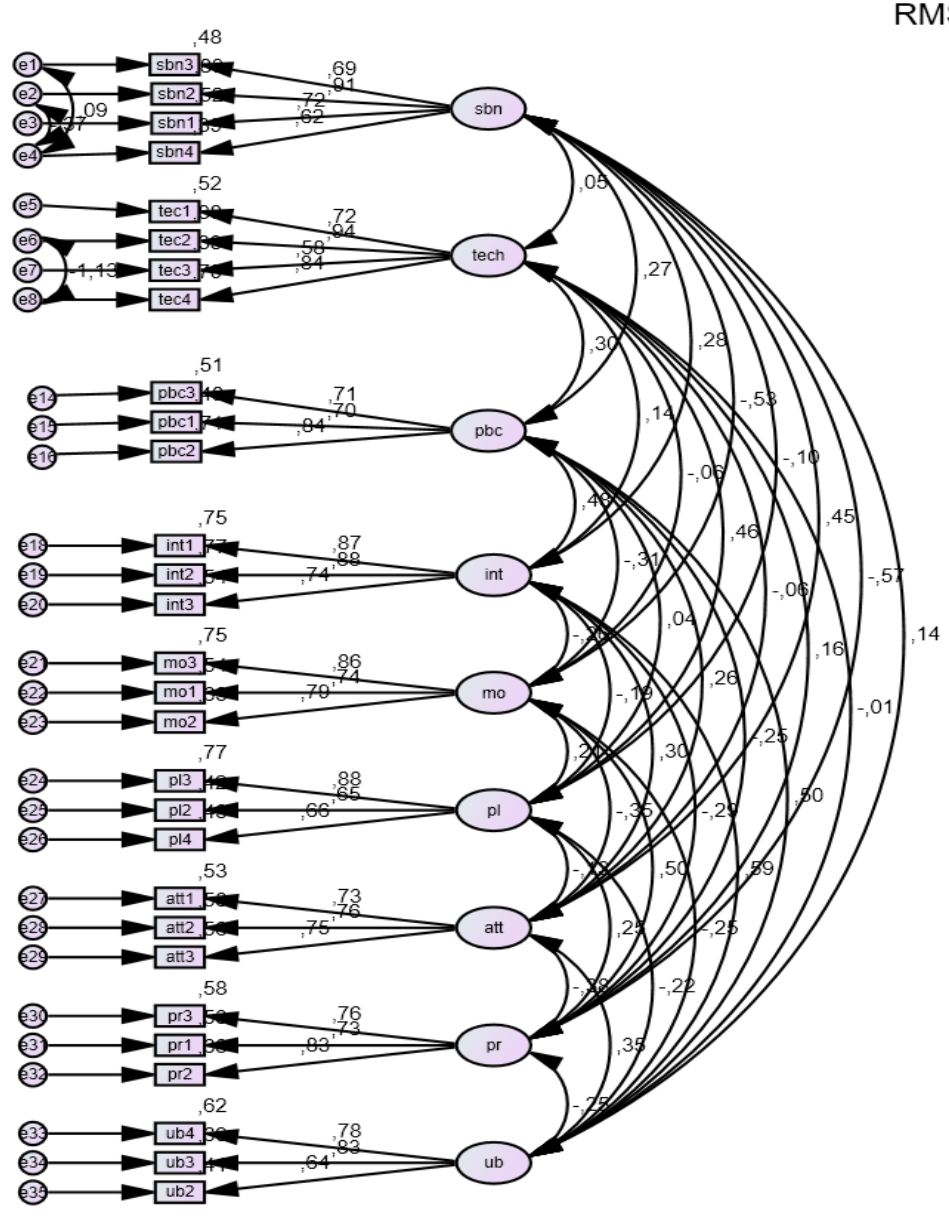

Figure 2: The result of the CFA model

Table 4: Structural equation model analysis results

\begin{tabular}{|c|c|c|c|c|}
\hline Hypothesis & Statement & $\begin{array}{l}\text { Standardized } \\
\text { estimation }\end{array}$ & $\mathbf{P}$ & Results \\
\hline $\mathrm{H} 1$ & Subjective norm $=>$ Intention & 0.08 & .282 & Reject \\
\hline $\mathrm{H} 2$ & Attitude $=>$ Intention & $0.17^{*}$ & .031 & Support \\
\hline H3 & Perceived behavioral control => Intention & $0.44^{\star \star \star}$ & **** & Support \\
\hline $\mathrm{H} 4$ & Regulation recognition $=>$ Intention & $-0.20^{\star *}$ & .003 & Support \\
\hline H5 & Moral obligation => Subjective norm & $-0.58^{\star \star *}$ & *** & Support \\
\hline H6 & Perceived risk $=>$ Attitude & $-0.22^{\star *}$ & .004 & Support \\
\hline $\mathrm{H} 7$ & Perceived risk => Perceived behavioral control & $-0.34^{\star \star \star}$ & 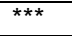 & Support \\
\hline $\mathrm{H} 8$ & Technology development => Perceived behavioral control & $0.37^{* \star \star}$ & $* * *$ & Support \\
\hline $\mathrm{H} 9$ & Subjective norm $=>$ Attitude & $0.38^{\star \star \star}$ & $* * *$ & Support \\
\hline $\mathrm{H} 10$ & Intention => Digital piracy behavior & $0.26^{\star * *}$ & $* * *$ & Support \\
\hline $\mathrm{H} 11$ & Perceived behavioral control => Digital piracy behavior & $0.47^{\star \star \star}$ & *** & Support \\
\hline
\end{tabular}

Significance level: ${ }^{*}(<0.05),{ }^{* *}(<0.01),{ }^{* * *}(<0.001)$

\subsection{Discussion}

In summary, the above analysis results are similar to previous researches. For example, Sim et al. [30] showed that male group is considered better in technology updating so that the rate of digital piracy is higher in the male group than in the female group. About the career and major of respondents, the technical group has a trend to conduct digital piracy behavior more than the non-technical group. Similarly, people in IT-Electronics and Engineering group tend to be easier to conduct digital piracy behavior than people in Economics group. 
However, there is no difference in digital piracy behavior between age groups, education levels, and income groups. This result could be reasoned by the less difference in the education level of respondents (>90\% got a university degree or higher), and by the similarity in the age of respondents (>90\% less than 35$)$. About the income, most of the respondents thought that the price of digital products (software) is fairly high $(71.6 \%$ agree). Therefore, income has no impact on digital piracy behavior. Besides, digital piracy in Vietnam could be seen as a habit and it becomes a cultural feature of Vietnamese people, so that, this behavior is not determined by their financial situation. This finding is also suitable with Yoon [43] and Udo et al. [33] that habit and culture impact strongly on digital piracy behavior.

Table 5: ANOVA analysis results

\begin{tabular}{|l|l|l|l|l|}
\hline & $\begin{array}{l}\text { Homogeneity } \\
\text { of variances }\end{array}$ & ANOVA test & Post Hoc (Tamhane's T2) & Conclusion \\
\hline H12b: Age & $\begin{array}{l}\text { Sig. }=0.529> \\
0.05\end{array}$ & Sig. $=0.152>0.05$ & & $\begin{array}{l}\text { No significant difference between } \\
\text { age groups. }\end{array}$ \\
\hline $\begin{array}{l}\text { H12c: } \\
\text { Education } \\
\text { level }\end{array}$ & $\begin{array}{l}\text { Sig. }=0.743> \\
0.05\end{array}$ & Sig. $=0.312>0.05$ & & $\begin{array}{l}\text { No significant difference between } \\
\text { education levels. }\end{array}$ \\
\hline $\begin{array}{l}\text { H12d: } \\
\text { Career }\end{array}$ & $\begin{array}{l}\text { Sig. }=0.350> \\
0.05\end{array}$ & Sig. $=0.009<0.05$ & $\begin{array}{l}\text { Sig. }=0.012<0.05 \\
\text { (Technical/ Nontechnical) }\end{array}$ & $\begin{array}{l}\text { There is a difference between } \\
\text { Technical worker and Non-technical } \\
\text { worker }\end{array}$ \\
\hline $\begin{array}{l}\text { H12e: } \\
\text { Major }\end{array}$ & $\begin{array}{l}\text { Sig. }=0.165> \\
0.05\end{array}$ & Sig. $=0.000<0.05$ & $\begin{array}{l}\text { Sig. }=0.000<0.05 \text { (IT- } \\
\text { Electronics/ Economics) } \\
\text { Sig. }=0.000<0.05 \\
\text { (Other Engineering/ } \\
\text { Economics) }\end{array}$ & $\begin{array}{l}\text { There is a difference between } \\
\text { Economics group and IT-Electronics/ } \\
\text { between Economics group and } \\
\text { Other engineering groups. }\end{array}$ \\
\hline $\begin{array}{l}\text { H12f: } \\
\text { Income }\end{array}$ & $\begin{array}{l}\text { Sig.=0.474> }>0.05 \text { between groups } \\
0.05\end{array}$ & Sig. $=0.042<0.05$ & $\begin{array}{l}\text { Sig. }>\text { significant difference between } \\
\text { income groups. }\end{array}$ \\
\hline
\end{tabular}

Moreover, according to Higgins et al. [18], people with characteristics of low self-control are likely to perform digital piracy, while two other dimensions of self-control (the social bonding and the self-generated view of inhibitions) have a negative link with the likelihood of performing digital piracy. So, these findings are confirmed by this research because the attitude factor is similar to the individual characteristic, and the regulation recognition and the moral obligation are somehow related to the view of inhibitions and the social bonding.

Besides, according to Hill [19], one of the causes of digital piracy behavior is the inequality perception of pirates toward high price digital products. Therefore, regulation recognition is important, but not enough to mitigate the digital piracy situation in Vietnam. In order to change users' attitudes toward digital piracy, a more flexible strategy needs to be formed at both the national level and business level. A suitable strategy will help to increase equality in society and to reduce the digital gap between the poor and the rich. Some practical solutions could be considered, including encouraging the use of free/open source products, releasing more freeware or shareware, changing the business model toward a more difficult-to-pirate product or service, etc.

\section{Findings \& Managerial Implications}

This section will summarize some main findings of the research, and it will provide some managerial implications based on analysis results for mitigating the digital piracy behavior in Vietnam.

\subsection{Findings}

In general, some main findings of the research could be summarized as follows:

- The most influencing factor on the intention toward digital piracy is a moral obligation (beta=-0.58), which indicates the important role of the cultural factor and ethical concerns of individuals in the context of Vietnam. This finding is suitable with previous researches ([19], [21], [42]).

- Perceived behavioral control has strong impacts on both the intention and behavior of digital piracy (beta $=0.44$, and beta $=0.47$ relatively). This result was rarely mentioned in previous researches, but it confirmed our thoughts about the important role of technology and users' computer competent in this kind of action. So, deterrence technologies should be developed and those websites sharing cracking experiences should be prohibited for improving the digital piracy situation in Vietnam.

- Perceived risk also has a strong negative impact on both perceived behavioral control (beta=-0.34) and the attitude toward digital piracy (beta=-0.22). Therefore, raising the understanding of users about the risk of digital piracy, such as virus-infected, bad effects on their devices, punishments..., could help to prevent this behavior in practice. This factor also relates to economic factors in previous researches ([21], [39]). 
- Regulation recognition has a negative impact on the intention of digital piracy (beta=-0.20). This result showed the important role of intellectual property regulation and related law in preventing digital piracy behavior. Moreover, how to let users know and follow the regulation is also important. This result is suitable with previous researches ([20], [25]).

- $\quad$ About the demographic factors, there are some differences in digital piracy behavior between male and female (gender); technical group and non-technical group (career); Engineering group and Economics group (major). However, in this result, there is no difference in digital piracy by age, education level and income. In contrast with our thoughts, this result showed that the impact of economic factors (income, price) on digital piracy is not significant. This result could be explained by the relatively low income of most of the respondents in the sample and their similar perception about the high price of the digital products.

\subsection{Managerial Implications}

From the above results, some managerial implications for preventing digital piracy behavior in Vietnam could be suggested as follows:

- Raising the moral obligation of Vietnamese users: a collaboration between businesses, government, and universities should be established for educating and forming ethical standards in the digital age. This ethical standard must be suitable with global value in using and protecting digital products. Besides, some solutions for changing gradually the habit of Vietnamese students should be implemented in order to reduce the digital piracy behavior in the future, such as: forcing the use of copyrighted e-book or licensed software, organizing seminars about ethical behavior in using the computer and the internet...

- Reducing the perceived behavioral control by using deterrence technologies: Deterrence technology (security methods, encoding, encrypted, certification...) should be developed to prevent hackers or crackers. Besides, some sharing communities on cracking experience, such as black websites, illegal forums, and online file-sharing communities should be prevented and their users should be warned of heavy punishments if they pirate digital products. Moreover, informing users of illegal products or providing them updating versions could help to eliminate the illegal use of these products.

- Increasing the perceived risk in digital piracy: Copyright holders and schools should train users of digital products about the problems occurred with their devices in using illegal products or cracked versions. Besides, digital product providers should think of a flexible strategy in delivering their products to poor countries by using dynamic pricing for their products (freeware, shareware, low price for limited version...).

- Improving the regulation recognition of citizens in intellectual property: Although there is an intellectual property law in Vietnam, the understanding of the people about these regulations is low and the real application of these regulations is not effective. Therefore, some recommendations for Vietnamese government include: educating and informing people about intellectual property regulations; using films or mass media to raise the awareness of people about the consequences of digital piracy; adapting the current regulations to be more applicable and heavier punishment; and checking the real use of illegal digital products at both business and individual level.

- Encouraging the use of free/ open-source software and reducing the price of digital products: In order to reduce the digital piracy, utilization of free/open-source software could be a possible option for students and small enterprises. Besides, reducing the price of digital products could help to make digital products easy to buy for average income people. Other options to get digital products at a cheaper price should also be used, such as software renting, cloud services, free version, limited version or shared version, etc.

\section{Conclusion \& Future Work}

This section will conclude the paper and give comments on its limitations and future research directions.

\subsection{Conclusion}

In general, based on previous researches, an integrated research model has been proposed for examining the impact factors of digital piracy behavior in Vietnam. The main contribution of this research is to form a relative coherence model from various viewpoints (psychological, ethical, legal, economic, and technological) to understand the causes of digital piracy intention and behavior of users in Vietnam. The testing result from 264 valid respondents supported most of the proposed hypotheses.

The empirical result showed that digital piracy behavior in Vietnam is determined by the intention of this behavior (beta=0.26), and the perceived behavioral control (beta=0.47). The reason for the strong impact of the perceived 
behavioral control is in the easiness of searching, cracking and using unlicensed digital products in Vietnam context. Perceived behavioral control also supported by the fast development of technology, sharing forums and an Internet connection (beta=0.37), but it is negatively affected by the perceived risk (beta=-0.34).

Besides, the result showed that the intention toward digital piracy is positively affected by the attitude (beta=0.17), and the perceived behavioral control (beta=0.44). But, the intention is negatively affected by the regulation recognition (beta $=-0.20$ ), the moral obligation (beta=-0.58), and the perceived risk (beta $=-0.22$ ). However, the intention is not affected by the subjective norm. It may be because of the norm in Vietnam is not against digital piracy behavior. Some people in Vietnam even think that a hacker is a talented person in Computer [27]. In this result, the subjective norm has a strong impact on the attitude toward digital piracy behavior (beta=0.38). This is similar to several previous pieces of research ([20], [22]).

Moreover, the research also realized the difference in digital piracy between demographic groups, such as gender, career and major. But, there is no difference in digital piracy behavior between other groups classified by age, education level, and income. In order to check the impact of economic factors (income, price), a question about the users' perception of the price of digital products in comparison with the average income was also added. The result showed that the current price of digital products was thought to be high (mean $=3.9 / 5$ ) to respondents. Besides, another problem for digital piracy behavior was found to be the difficulty in the payment of digital products, especially in making the payment for foreign providers. Therefore, reducing the price of digital products and overcoming problems in online payment for digital products could help to improve the situation in Vietnam.

\subsection{Implications for Future Researches}

Some limitations of the research could be summarized as follows: (1) small sample size and limited in one city in Vietnam reduced the ability to generalize the result, (2) convenience sampling method and one-time data collection could not measure exactly the causality relationships in the model, and (3) Low $R^{2}$ coefficient $(<50 \%)$ showed that some other factors could be missed in the proposed research model.

Therefore, some future research directions should include: (1) extends the scope of data collection to other cities in Vietnam or to other similar countries, (2) applies multiple time-points data collection or time series sample to measure the causal effect of impact factors on dependent factors, and (3) adds some other factors related to culture, economy, habit... to the research to better explain the digital piracy behavior in Vietnam.

\section{Acknowledgments}

I would like to gratefully acknowledge the support of Vietnam National University in Ho Chi Minh City (VNU-HCM) for this Research Project (Grant number C2017-20-41).

\section{References}

[1] I. Ajzen, The theory of planned behavior, Organizational Behavior Human Decision Process, vol. 50, no. 2, pp. 179-211, 1991.

[2] I. Ajzen, Perceived behavioral control, self-efficacy, locus of control, and the theory of planned behavior, Journal of Applied Social Psychology, vol. 32, pp. 665-683, 2002.

[3] S. Al-Rafee and T.P. Cronan, Digital piracy: Factors that influence attitude toward behavior, Journal of Business Ethics, vol. 63, no. 3, pp. 237-259, 2006.

[4] S. Al-Rafee and K. Rouibah, The fight against digital piracy: An experiment, Telematics and Informatics, vol. 27, no. 3, pp. 283-292 2010.

[5] A.R. Andrés, The relationship between copyright software protection and piracy: Evidence from Europe, European Journal of Law and Economics, vol. 21, no. 1, pp. 29-51, 2006.

[6] S. Bhattacharjee, R. Gopal and G. Sanders, Digital music and online sharing: Software piracy 2.0 ? Communications of the ACM, vol. 46, no. 107-111, 2003.

[7] Business Software Alliance. (2016, May) Seizing opportunity through license compliance. BSA. [Online]. Available: https://globalstudy.bsa.org/2016/.

[8] CAGS. (2019, June) A guide to intellectual property for graduate students and postdoctoral scholars. Canadian Association for Graduate Studies. [Online]. Available: http://www.cags.ca/

[9] M. K. Chang, Predicting unethical behavior: A comparison of the theory of reasoned action on the theory of planned behavior, Journal of Business Ethics, vol. 17, no. 16, pp. 1825-1834, 1998.

[10] J. Chiou, C. Huang and H. Lee, The ntecedents of music piracy attitudes and intentions, Journal of Business Ethics, vol. 57, no. 2, pp. 161-174, 2005.

[11] T. P. Cronan and S. Al-Rafee, Factors that Influence the Intention to pirate software and media, Journal of Business Ethics, vol. 78, no. 4, pp. 527-545, 2008.

[12] R. D. Gopal and G. L. Sanders, Preventive and deterrent controls for software piracy, Journal of Management Information Systems, vol. 13, no. 4, pp. 29-47, 1997. 
[13] R. D. Gopal and G. L. Sanders, International software piracy: Analysis of key issues and impacts, Information Systems Research, vol. 9, no. 4, pp. 380-397, 1998.

[14] R. D. Gopal, G. L. Sanders, S. Bhattacharjee, M. Agrawal and S. C. Wagner, A behavioral model of digital music piracy, Journal of Organizational Computing and Electronic Commerce, vol. 14, no. 2, pp. 89-105, 2009.

[15] R. Haines and D. Haines, Fairness, guilt, and perceived importance as antecedents of intellectual property piracy intentions, in Proceedings of the 28th International Conference on Information Systems, Montreal, 2007, pp. 158-173.

[16] R. Haines and L.N.K. Leonard, Situational influences on ethical decision-making in an IT context, Information and Management, vol. 44, no. 3, pp. 313-320, 2007

[17] J.F. Hair, W.C. Black, B.J. Babin, and R.E. Anderson, Multivariate Data Analysis. Upper Saddle River. New Jersey: Prentice Hall, 2010.

[18] G.E. Higgins, S.E. Wolfe and C.D. Marcum, Digital piracy: An examination of three measurements of selfcontrol, Deviant Behavior, vol. 29, no. 5, pp. 440-461, 2008.

[19] C.W.L. Hill, Digital piracy: Causes, consequences, and strategic responses, Asia Pacific Journal of Management, vol. 24, no. 1, pp. 9-25, 2007

[20] T. P. T. Hoang and H. H. Ha, Attitude and intention toward software piracy of Vietnamese students, Science \& Technology Development Journal, vol.17, no.4Q, 2014.

[21] K.M. Koklic, M. Kukar-Kinney, and I. Vida, Three-level mechanism of consumer digital piracy: Development and cross-cultural validation, Journal of Business Ethics, vol. 136, no. 1, pp. 15-27, 2016.

[22] C. Liao, H. Lin and Y. Liu, Predicting the use of pirated software: A contingency model integrating perceived risk with the theory of planned behavior, Journal of Business Ethics, vol. 91, no. 2, pp. 237-253, 2010

[23] D.T. Nguyen and T.M.T. Nguyen, Scientific Research in Business Administration, Ha Noi: Statistic Publishing House, 2009

[24] A. Nill and C. Shultz, Global software piracy: Trends and strategic considerations, Business Horizons, vol. 52, no. 3, pp. 289-298, 2009 .

[25] G. Peace, D. Galletta and L. Thong, software piracy in the workplace: A model and empirical test, Journal of Management Information Systems, vol. 20, no. 1, pp. 153-177, 2003.

[26] Q. T. Pham, Knowledge Management Textbook. Ha Noi: Construction Publishing House, 2016.

[27] Q. T. Pham, A Knowledge Management Approach of Ensuring the Success of IT Industries in Vietnam. New York: Nova Science Publishers, 2017.

[28] Y. Sang, J. Lee, Y. Kim, and H. Woo, Understanding the intentions behind illegal downloading: A comparative study of American and Korean college students, Telematics and Informatics, vol. 32, no. 2, pp. 333-343, 2014.

[29] R.A. Shang, Y.C. Chen and P.C. Chen, Ethical decisions about sharing music files in the P2P environment, Journal of Business Ethics, vol. 80, no. 2, pp. 349-365, 2008.

[30] R. R. Sims, H. K. Cheng and H. Teegen, Toward a profile of student software pirates, Journal of Business Ethics, vol. 15, no 8, pp. 839-849, 1996.

[31] M. Siponen and T. Vartiainen, Unauthorized copying of software and levels of moral development: A literature analysis and its implications for research and practice, Information Systems Journal, vol. 14, no. 4, pp. 387-407, 2004.

[32] S. Taylor and P. Todd, Understanding information technology usage: a test of competing models, Information Systems Research, vol. 6, no. 2, pp. 144-176, 1995.

[33] G. Udo, K. Bagchi and M. Maity, Exploring factors affecting digital piracy using the norm activation and UTAUT models: The role of national culture, Journal of Business Ethics, vol. 135, no. 3, pp. 517-541, 2016.

[34] VECOM. (2018) Vietnam e-business index 2018. Vietnam E-commerce Association. [Online]. Available: http://www.vecom.com/

[35] V. Venkatesh, M. Morris, G. Davis, and F. Davis, User acceptance of information technology: Toward a unified view, MIS Quarterly, vol. 7, no. 3, pp. 425-478, 2003.

[36] V. Venkatesh, Y. L. M. Thong and X. Xu, Consumer acceptance and use of information technology: Extending the unified theory of acceptance and use of technology, MIS Quarterly, vol. 36, no. 1, pp. 157-178, 2012.

[37] Vietnam Ministry of Justice (VMJ). (2014) Vietnam law documents \& database. Legal Normative Documentos. [Online]. Available: http://vbpl.vn/Pages/portal.aspx

[38] I. Vida, M. Kukar-Kinney, M. K. Koklic, and J. Reardon, National culture dimensions and consumer digital piracy: A European perspective, in Proceedings Atlantic Marketing Association, Savannah, GA, 2015, pp. 1-5.

[39] I. Vida, M. K. Koklič, M. Kukar-Kinney, and E. Penz, Predicting consumer digital piracy behavior: The role of rationalization and perceived consequences, Journal of Research in Interactive Marketing, vol. 6, no. 4, pp. 298-313, 2012

[40] D. J. Woolley and M. M. Eining, Software piracy among accounting students: A longitudinal comparison of changes and sensitivity, Journal of Information Systems, vol. 20, no. 1, pp. 49-63, 2006.

[41] H. Wulandari, Economy and technology as influential factors for digital piracy sustainability: An Indonesian case, Procedia - Social and Behavioral Sciences, vol. 164, pp. 112-117, 2014.

[42] C. Yoon, Theory of planned behavior and ethics theory in digital piracy: An integrated model, Journal of Business Ethics, vol. 100, no. 3, pp. 405-417, 2011

[43] C. Yoon, Digital piracy intention: a comparison of theoretical models, Behavior \& Information Technology, vol. 31, no. 6, pp. 565-576, 2012.

[44] S. Yubero, E. Larrañaga, B. Villora, and R. Navarro, Negative peer relationships on piracy behavior: A crosssectional study of the associations between cyberbullying involvement and digital iracy, International Journal of Environmental Research and Public Health, vol. 14, no. 10, p. 1180, 2017. 


\section{Appendix A: Measurement Scales}

\begin{tabular}{|c|c|}
\hline \multicolumn{2}{|c|}{ Attitude toward digital piracy } \\
\hline ATT1 & Digital piracy is a wise idea \\
\hline ATT2 & Digital piracy is a beneficial idea \\
\hline ATT3 & Digital piracy is a good idea \\
\hline ATT4 & Overall, my attitude toward digital piracy is favorable \\
\hline \multicolumn{2}{|c|}{ Subjective norm } \\
\hline SBN1 & If I pirated digital products, most of the people who are important to me would disapprove \\
\hline SBN2 & Most people who are important to me would look down on me if I pirated digital products \\
\hline SBN3 & No one who is important to me thinks it is okay to commit digital piracy \\
\hline SBN4 & My colleagues think digital piracy behavior is wrong \\
\hline \multicolumn{2}{|c|}{ Perceived behavioral control } \\
\hline PBC1 & For me, it is easy to possess pirated digital products \\
\hline PBC2 & I have the knowledge and ability to make use of pirated digital products \\
\hline PBC3 & I could find pirated digital products if I wanted to \\
\hline PBC4 & Pirating digital products is entirely within my control \\
\hline \multicolumn{2}{|c|}{ Perceived risk } \\
\hline PR1 & If I pirated digital products, I would probably be caught \\
\hline PR2 & I would be arrested for infringement of the copyright law if I used pirated digital products \\
\hline PR3 & If I was arrested for infringement of the copyright law, I would receive a heavy fine \\
\hline PR4 & Illegally downloading files is risky because my devices may be infected by the virus. \\
\hline PR5 & Illegally downloading files could allow access to my personal data, files or passwords \\
\hline \multicolumn{2}{|r|}{ Regulation recognition } \\
\hline PL1 & Even though downloading the music is illegal, it's no big deal or the law would be enforced more \\
\hline PL2 & Laws about downloading unlicensed software are not enforced \\
\hline PL3 & Digital piracy is unfair to the producer of digital products \\
\hline PL4 & In general, digital piracy is unjust \\
\hline PL5 & Digital products should be protected by copyright \\
\hline \multicolumn{2}{|c|}{ Moral obligation } \\
\hline MO1 & I would feel guilty if I pirated digital products \\
\hline MO2 & To pirate digital products goes against my principles \\
\hline MO3 & It would be morally wrong for me to pirate digital products \\
\hline MO4 & Overall, digital piracy is ethically acceptable \\
\hline MO5 & When things went wrong, I try not to blame others \\
\hline MO6 & I mostly try not to violate laws, rules, and regulations \\
\hline \multicolumn{2}{|c|}{ Technology development } \\
\hline TEC1 & The Internet connection in various forms is available. \\
\hline TEC2 & The access and download speed is high \\
\hline TEC3 & There are many online communities sharing experiences in digital piracy. \\
\hline TEC4 & It is easy to access P2P file-sharing sites (F-share, 4share...) \\
\hline \multicolumn{2}{|c|}{ Intention to digital piracy } \\
\hline INT1 & I intend to pirate digital products in the near future \\
\hline INT2 & If I have a chance, I will pirate digital products \\
\hline INT3 & I never commit digital piracy \\
\hline \multicolumn{2}{|c|}{ Digital piracy behavior } \\
\hline UB1 & I often pirated digital products. \\
\hline UB2 & I often used pirated digital products. \\
\hline UB3 & I often share pirated digital products. \\
\hline UB4 & I encouraged other people to use pirated digital products. \\
\hline
\end{tabular}

